\title{
Market-Driven Management, Global Markets and Competitive Convergence
}

\author{
Elisa Rancati*
}

\begin{abstract}
Global markets redefine competition space, fostering a collaborative network between companies (market-driven management). Globalisation causes previously distinct global economies to converge into a single large market, thus generating fusion between competitive environments that are not only differentiated but also often very distant (competitive convergence).
\end{abstract}

Keywords: Competitive Convergence; Competitive Landscape; Global Competition; Global Markets

\section{The Competitive Horizon of Domestic Markets and Global Markets}

On closed, static markets, companies compete in a defined space, the sector, in which territorial and administrative boundaries are clear-cut and stable in time, and whose structure influences corporate strategies. The definition of the sectorial boundaries within which the companies measure their competitive profile is simple and immediate, because it is based on the total homogeneity of the product inside the sector, and on the radical difference in the products from two different sectors, to the point that their intersecting elasticity is taken to be nil (Edward 1955).

Traditional analysis of the sector is carried out in a given timeframe ' $t$ ' through the paradigm based on the structure-conduct-performance triad: structural conditions, and concentration in particular, can determine companies' behaviour and performance, seen as the end result of competition (Schumpeter 1982). Sector structures are the organisational characteristics that influence the way companies compete (for example the degree of concentration of salesmen or the degree of product differentiation). Other general parameters of significance, studied in detail in a structuralist analysis of a sector, are concentration (measured by the concentration ratio, the Herfindahl index, the $\mathrm{N}$ equivalent number, the entropic index, the Gini Index, the Lorenz curve and the Linda Index), vertical integration and economies of scale. The structure of the sector provides precise indications

\footnotetext{
*Assistant Professor of Management, University of Milan-Bicocca (elisa.rancati@unimib.it)

Edited by: ISTEI - University of Milan-Bicocca

ISSN: $1593-0319$

Rancati Elisa, Market-Driven Management, Global Markets and Competitive Convergence, Symphonya. Emerging Issues in Management (symphonya.unimib.it), n. 1, 2010, pp. 76-85

http://dx.doi.org/10.4468/2010.1.08rancati
} 
about the behaviour adopted by companies to implement processes to adapt to conditions on the market where they operate (competitive conduct).

On closed markets, a competitor is a company that belongs clearly and definitely to the same area of activity as the company considered (direct competition).

\begin{abstract}
$\square$ 'When we describe competition as an element that regulates a company's products and prices, we normally refer to competition between companies that are already established in a specific sector we wish to refer to. In terms of market conduct, we consider in particular whether the price policies of successful companies are formulated independently or in the light of a 'clearly recognised mutual interdependence', whether any collusion exists between these companies, and, if it does, if this collusion is imperfect in any way. In terms of the market structure, a great deal of attention is paid to the characteristics that presumably influence the competitive behaviour of well-established rival companies and, in particular, to the number, distribution and size of these rival companies and the way in which their respective products differ from each other. In any case, the most attention is usually focused on the immediate competition between established companies' (Bain 1975 p. 18).
\end{abstract}

The concept of competition comes to mean rivalry between companies, in other words, a situation in which each company is exposed to the threat deriving from the behaviour of the others. Only if rivalry exists between companies can competition exist. Companies can take advantage of competition through two characteristic parameters of the structure of the sector: the first parameter is the creation of a cost advantage the product being equal (cost differentiation); the second on the other hand derives from offering the customer a product with peculiar characteristics that differ from those offered by a competitor (product differentiation).

'The fundamental basis of above average profitability in the long run is sustainable competitive advantage. Although a company may have infinite strengths and weaknesses compared to its competitors, there are two basic types of competitive advantages a firm can possess: low cost or differentiation. The significance of any company strength or weakness essentially reflects its impact on the relative cost or on differentiation. Cost advantage and differentiation in turn depend on the structure of the industrial sector' (Porter 1985 p. 35).

On closed markets, one of the factors that generate sensitive competition differentials between companies is economies of scale, which make it possible to identify one or more optimal minimal dimension.

In global, very open markets, the competitive significance of the sector of activity is attenuated: the multi-business company is no longer defined by precise space and time coordinates. Globalisation determines new competition boundaries between companies, modifying the traditional time and space relations that underpin 
competition. Global dynamism obliges companies to be dynamic when defining boundaries.

\section{Global Markets and Competitive Convergence}

Globalisation increases the level of interdependence between markets, because it increases financial, commercial and cultural exchanges, breaking down the barriers that hinder the transfer of goods, services, capital, resources, information and technology between the various countries. This changes the configuration of a company's competitive horizon by modifying the competition boundaries; space is no longer characterised by distance and by territorial or administrative frontiers (market-space management). This transforms the organisation within the competition space of the relations and transactions of any company that focuses on time as a competitive driver (time-based competition).

In fact, on global markets, competition space is defined by the following main features: it is born from market-space management; it is the 'place' where direct and indirect competitive relations are played out; it excludes the possibility of being outlined in precise sectors of elementary activity established over the years (Brondoni 2008); it causes previously distinct global economies to converge into a single large market, thus generating fusion between competitive environments that are not only differentiated but also often very distant (competitive convergence).

$\square$ 'The convergence may not solely be limited to telephone and computing-related technologies. In particular, emerging scientific advances in the intersection of microelectronics, material design, molecular biology, as well as complex chemistry result in nanoscale developments, which may trigger similar industry phenomena. The consulting firm McKinsey \& Company estimates that the cumulative market for converging info-, bio-, and nanotechnologies could top 1 trillion dollars within a decade ... The convergence phenomenon should take a centre stage in the research and theory on technological change, innovation and corporate strategy' (Hacklin 2010 p. 18).

Global markets are interconnected, and there is a gradual shading of the distinctions between goods and services, buyers and sellers, tangible and intangible resources and two or more companies (Davis, Meyer 1998).

$\square$ For example, the subprime mortgage phenomenon and the resulting financial crisis that hit the United States in the first half of 2007, has impacted negatively on the entire global economy, dragging Western countries into a recession, also underlined by the collapse of authentic industrial giants in the world market (the Merrill Lynch case in the USA or the Lehman Brothers crash).

$\square$ 'An economy that is highly integrated in a worldwide network becomes increasingly vulnerable to external shocks such as devaluation, a sudden 
hike in oil prices, a financial crisis or the threat of war. This has important managerial implications. $<\ldots>$ In the global economy, the role of strategic marketing is more important than ever. It remains the best mechanism to balance demand and supply and it also triggers a virtuous circle of economic and social development, strengthened today by the social, cultural and technological changes observed in the market' (Lambin 2002 p. 15).

A global company competes directly or indirectly inside a competitive ecosystem (Moore 1996; Lambin 2008) that is defined as 'a complex group of companies and consumers, suppliers, competitors, distributors, specifiers and partners who benefit mutually from each other' (Manning, Thorne 2003 p. 76) in which the geographical or bureaucratic boundaries of the company - if they exist - overlap and are confused, fluid and dynamic.

'As markets globalise, numerous frontiers are swept away, intangible aspects replace tangible elements, time becomes a critical factor of existence, and mobility (of people, goods, knowledge and ideas) establishes new types of relationships in the context of global managerial economics. In global markets, companies therefore compete according to market-space competition logics, i.e. competition boundaries in which space is not a fact, a known, stable element of decision-making process, but a competitive factor whose profile is shaped and modified by the actions/reactions of businesses and governments' (Brondoni 2008).

Competitive convergence does not cancel the companies' original areas of activity, but incorporates them into a broader competitive environment with a dual goal: to reduce costs ('builds on a common inventory, information and logistics base; reduces cost of contacting customers and other interaction costs; virtual communities can help reduce the cost of company supplied information and support') and to achieve a potential increase in profits ('reaches both cyber and traditional segments; achieves synergies between the online and offline businesses that promote sales; increases access to the business, anytime, anywhere; premium services such as customization, home delivery and choice tools increase the stickiness and allow companies to charge a premium price') (Rosen 2009 p. 25).

The origins of the convergence can be traced back to Chamberlin's study, the introduction of the concept of differentiation and the resulting chain of interdependence (Chamberlin 1933).

Competitive convergence redefines the competition space, asserting complex corporate competitive systems that are open, flexible and ramified, and which tend to converge in the same open competitive space. Competitive convergence based on market-space management therefore translates into a substantial expansion of the competitive base, thus representing a form of indirect competition.

The realisation and defence of the competitive advantage forces global companies with weak boundaries to activate a dense network of cooperation and collaboration, first of all with suppliers and customers, and subsequently with other stakeholders, occasionally even including competitors ('co-opetition'). 
$\square$ 'In the market you have to listen to customers, work with suppliers, create teams, establish strategic partnerships - even with competitors. That doesn't sound like war. There are few victors when business is conducted as war. The typical result of a price war is surrendered profits all around. Just look at the U.S. airline industry: it lost more money in the price war of 1990-93 than it had previously made in all the time since Orville and Wilbur Wright' (Nalebuff, Brandenburger 1996 p. 5).

Global companies tends frequently to de-verticalise, to forge alliances and trading or commercial agreements, to establish strategic competition-collaboration relations, eliminating the sense of antagonism and rivalry from competition so that it becomes cooperation.

$\square$ 'Globalisation and over-supply impose a new market-oriented
management philosophy on companies, in which customer value
management prevails, in other words, sales to demand bubbles (instable
aggregates of clientele that replace demand segments) with direct and
continuous confrontation with competitors. In this context, for example,
Toyota and PSA produce three versions of the same model together
(Toyota Aygo, Citroen C1, Peugeot 107) - locating the new plant in the
Czech Republic - to meet demand bubbles for city cars with a low price,
safety and personality' (Brondoni 2008).

Corporate competitive systems derive from convergence in the technological, manufacturing and commercial relations forged by independent companies - even when they compete against each other - and they aim to exploit the advantages of mutual complementarity.

$\square$ 'Whereas the concept of convergence has represented a subject of attention within the telecommunications and information technology (IT) sectors for over a decade now, recent industrial trends suggest that the initially developed visions finally start to become operational, and that the convergence phenomenon increasingly is jumping 'from drawing board concept into consumers' hands, (...) bringing users' media consumption closer to the nirvana of anything, anytime, anywhere' (Hacklin 2010 p. 67).

The process of competitive convergence between companies is a typical expression of global managerial economics founded on the expansion of competitive horizons and a continuous striving for innovation that can result in an appreciable advantage over other companies.

\section{Market-Driven Management and Competitive Convergence}

Market-driven management originates from global managerial economics focused on competitive convergence. Market-driven global companies have modified their 
competitive strategies regarding the extension of competition space (market-space management), experimenting with different business models and acquiring new organisational models compared to the past. Not only does the competition space (market-space management) referred to for the competitive benchmarking appear to be in many ways without limitations, but even the time necessary to complete a process of convergence also contracts significantly. The growing convergence between new technologies helps to shrink distances, and considerably reduces communication transmission times (time-based competition).

Typical examples of strategies based on competitive convergence can be found in corporations like General Electric, Toyota or Siemens.

- General Electric is a global infrastructure, finance and media company taking on the world's toughest challenges. From everyday light bulbs to fuel cell technology, to cleaner, more efficient jet engines, GE has continually shaped our world with groundbreaking innovations for over 130 years. GE has a strong set of global businesses in infrastructure, finance and media aligned to meet today's needs, including the demand for global infrastructure; growing and changing demographics that need access to healthcare, finance, and information and entertainment, and environmental technologies. GE businesses are: appliances, aviation, consumer products, electrical distribution, energy, finance, healthcare, lighting, media and entertainment, oil and gas, rail, software and services, water' (www.ge.com/company).

$\square$ 'Siemens has been synonymous with international focus and worldwide presence for over 160 years. Today, Siemens is a global powerhouse with activities in nearly 190 regions. Businesses are: automation, building technologies, communication networks, consumer products, drive technology, energy, financial solutions, healthcare, IT solutions and services, lightning (OSRAM), mobility' (www.siemens.com).

Competitive convergence is often achieved by policies to develop partnership networks with the competition to rapidly satisfy demand bubbles by offering highly innovative products, thus becoming a strategy that monitors the dynamism of global competition and the instability of demand.

$\square$ 'GM is the majority shareholder in GM Daewoo Auto and Technology Co. of South Korea, and has product, powertrain and purchasing collaborations with Suzuki Motor Corp. and Isuku Motors Ltd. of Japan. GM also has advanced technology collaborations with Chrysler LLC, Daimler AG, BMW AG and Toyota Motor Corp. and vehicle manufacturing ventures with several automakers around the world, including Toyota, Suzuki, Shanghai Automotive Industry Corp. of China, AVTOVAZ of Russia and Renault SA of France' (www.gm.com).

Processes of corporate competitive convergence produce considerable changes in global corporate management, due to: 
- convergence between competitive network relations: globalisation demands groups of companies that operate in a variety of markets, linked by sophisticated forms of contact and complementarity (networks). In competitive corporate systems, convergence also occurs in the localisation of companies; in fact, in global economies, the concept of localisation extends beyond the significance of occupying space, to identify a business model that uses localisation dynamically to accumulate competitive advantage spaces;

$\square$ 'The ability to change quickly at ever-lower cost can be carried out at the strategic level first, and then translated into site operations. This suggests that business localization can acquire a dynamic character, and that such dynamism can be made concrete in two main ways. First, there can be a 'physical movement' of plants to different places (as in the case of geographically centralized businesses dividing themselves into smaller strategic business units (SBU), or in the case of transfer of an SBU to a different location). Second, dynamism can be implemented by agreements between businesses. A cooperative manufacturing agreement at a competitor's plant (the Fiat-Suzuki case) allows for a presence (albeit not independently) in an area. At the same time, the agreement implies loss of control over the site - thus manifesting the dynamic nature of manufacturing localization without any physical movement (of machinery or other tangible assets)' (Garbelli 2002).

- digital convergence: 'the principal characteristic of digital flows of communications and information lies in the possibility of channelling twoway flows from the issuer to the receiver and vice-versa. Any communications activity developed with digital technologies can envisage the return of information from the receiver to the issuer, even in an extremely simplified form (for example, a simple message receipt acknowledgement), which may have a high value for corporate management in terms of monitoring the effectiveness of any action taken' (Corniani 2008);

- convergence between distribution channels: competitive corporate systems use a variety of sales channels simultaneously (on and offline). The importance of the choice and converging management of distribution channels is considerably boosted on global markets with the same intensity with which new distribution formats have been established, with the capability of controlling and influencing outlet markets;

- convergence between corporate performances: the performance of corporate competitive systems is a multidimensional construct which summarises companies' ability to survive and to develop on the global markets. For these companies it becomes necessary to adopt a system of metrics to measure the economic, financial, social and competitive results, referred to corporate and product intangibles;

- convergence in competitive customer value: corporate competitive systems identify products with a higher value than those from competitors through direct, time-based benchmarking with global competition. The value for the 
customer is maximised by competitive convergence processes that regard the design and management of products to respond to instable demand bubbles.

$\square$ 'In global markets (and above all in over-suppliedied markets), the success of corporate strategies depends on the competitive relationships that a business establishes and the capacity to learn new and original frontiers of value from the market. A system of networking that strives for collaboration between internal, external and co-makership organisations, underlines the critical nature of a corporate information system based on new digital technologies, designed to instil value into relations with the intermediate and end customer, to generate competitive customer value advantages' (Brondoni 2009).

'Convergence marketing strategies for reaching the hybrid consumers are the following: convergence on customerization, convergence on communities, convergence on channels, convergence on competitive value, convergence on choice' (Wind, Mahajan 2002 p. 16).

The success of a convergence strategy is strongly conditioned by the system of intangible corporate resources:

- information system: converging global companies have to operate on markets that differ for geographical location and without space-time boundaries. The information processed must be up-to-date and timely because it allows companies to reduce uncertainties about the convergence process and therefore to contain risks;

- corporate identity: this embraces the potential of a reputation capable of encouraging the company's development through the acquisition and consolidation of competitive advantages in terms of cost containment and expansion of demand. Spreading the brand image over several products makes it possible to curb marketing costs and to exploit synergies in the implementation of development strategies in new areas of activity; it also simplifies and speeds up penetration of new markets (time-based competition). Behind brand extension strategies is the conceit that the brand's role of linking demand and supply can be transferred to different products (brand extension). In fact, brand extension strategies rely on the existence of synergies that allow recognition and image to be transferred between different supply systems and markets;

- corporate culture: in convergence processes the corporate culture is seen as a factor of global competition and represents a driver of competition space extension. Competitive convergence accentuates the intersection between the different facets of the social, environmental and cultural systems (crosscultural management). 


\section{Bibliography}

Bain Joe S., Barriers to New Competition: Their Character and Consequences in Manufacturing Industries, Harvard University Press, 1962.

Bergtsson Maria, Eriksson Jessica, Wincent Joakim, Co-Opetition Dynamics - an Outline of Further Inquiry, Competitiveness Review. An International Business Journal Incorporating Journal of Global Competitiveness, vol. 20, n. 2, 2010.

http://dx.doi.org/10.1108/10595421011029893

Bradley Stephen P., Hausman Jerry, Nolan Richard L. (eds.), Globalization, Technology and Competition. The Fusion of Computers and Telecommunications in the 1990s, Harvard Business School Press, Boston, 1993.

Brondoni Silvio M., Ouverture de 'Marketing Channels and Global Markets', Symphonya. Emerging Issues in Management (symphonya.unimib.it), n. 2, 2010. http://dx.doi.org/10.4468/2010.2.ouverture

Brondoni Silvio M., Market-Driven Management, Competitive Customer Value and Global Network, Symphonya. Emerging Issues in Management (symphonya.unimib.it), n. 1, 2009. http://dx.doi.org/10.4468/2009.1.02brondoni

Brondoni Silvio M., Ouverture de 'Market-Driven Management and Competitive Customer Value', Symphonya. Emerging Issues in Management (symphonya.unimib.it), n. 1, 2009. http://dx.doi.org/10.4468/2009.1.01ouverture

Brondoni Silvio M., Market-Driven Management, Competitive Space and Global Networks, Symphonya. Emerging Issues in Management (symphonya.unimib.it), n. 1, 2008. http://dx.doi.org/10.4468/2008.1.02brondoni

Brondoni Silvio M., Ouverture de 'Market-Driven Management and Global Markets', Symphonya. Emerging Issues in Management (symphonya.unimib.it), n. 2, 2008. http://dx.doi.org/10.4468/2008.2.01ouverture

Brondoni Silvio M., Global Markets and Market-Space Competition, Symphonya. Emerging Issues in Management (symphonya.unimib.it), n. 1, 2002. http://dx.doi.org/10.4468/2002.1.03brondoni

Chamberlin Edward H., The Theory of Monopolistic Competition: A Re-orientation of the Theory of Value, Harvard Business Press, Boston, 1933.

Corniani Margherita, Pull and Push Policy in Market-Driven Management Symphonya. Emerging Issues in Management (symphonya.unimib.it), n. 1, 2008. http://dx.doi.org/10.4468/2008.1.05corniani

Corniani Margherita, Demand Bubble Management, Symphonya. Emerging Issues in Management (symphonya.unimib.it), n. 1, 2002. http://dx.doi.org/10.4468/2002.1.08corniani

Davis Stan, Meyer Christopher, Blur. The Speed of Change in the Connected Economy, Addison Wesley, Boston, 1998.

Day George S., The Market-Driven Organization, Free Press, New York, 1999.

Day George S., Reibstein David J., Wharton on Dynamic Competitive Strategy, Wiley, New York, 2004.

Edwards Claude D., Conglomerate Bigness as a Source of Power, in Business Concentration and Price Policy, Princeton University Press, Princeton, 1955

Fahey Liam, Randall Robert. M., Learning form the Future. Competitive Foresight Scenarios, Wiley, New York, 1998.

Garbelli Maria E., Over-Supply and Manufacturing Localization, Symphonya. Emerging Issues in Management (symphonya.unimib.it), n. 1, 2002. 
http://dx.doi.org/10.4468/2002.1.10garbelli

Gnecchi Flavio, Market-Driven Management, Market Space and Value Proposition, Symphonya. Emerging Issues in Management (symphonya.unimib.it), n. 2, 2009. http://dx.doi.org/10.4468/2009.2.04gnecchi

Hacklin Fedrick, Management of Convergence in Innovation: Strategies and Capabilities for Value Creation Beyond Blurring Industry Boundaries, Physica-Verlag HD, London, 2010, pp. 18, 67.

Jones Susan, Spiegel Ted, Marketing Convergence, South Western Educational, London, 2002.

Kim Chan, Mauborgne Renee, Blue Ocean Strategy, Harvard Business School Press, Boston, 2005.

Lambin Jean-Jacques, Changing Market Relationship in The Internet Age, Presses Universitaires de Louvain, Louvain, 2008.

Lambin Jean-.Jacques, Strategic Marketing Revisited after September 11, Symphonya. Emerging Issues in Management (symphonya.unimib.it), n. 1, 2002, p. 15. http://dx.doi.org/10.4468/2002.1.02lambin

Langohr Patricia, Competitive Convergence And Divergence: Position and Capability Dynamics, Industrial Organisation I, n. 11, 2003.

Manning Bo, Thorne Chris, Demand Driven, Mc Graw Hill, New York, 2003.

Moore James, The Death of Competition, Harper Collins, New York, 1996.

Nalebuff Barry J., Brandenburger Adam M., Co-opetition: Competitive and cooperative business strategies for digital economy, Strategy and Leadership, vol. 25, n. 6, 1997. http://dx.doi.org/10.1108/eb054655

Nalebuff Barry J., Brandenburger Adam M., Co-opetition, Harper Collins, London, 1996, p. 5.

Porter Michael E., Competitive Advantage. Creating and Sustaining Superior Performance, Free Press, New York, 1985, p. 35.

Porter Michael, Millar Victor E., How information gives you a competitive advantage, Harvard Business Review, Boston, 1985.

Rader Linda, Convergence: New Strategies for Marketing Natural Gas and Electric Power, Pennwell Books, New York, 2001.

Ringland Gill, Scenario Planning. Managing for The Future, Wiley, Chichester, 1998.

Rosen Richard D., Convergence Marketing, Wiley, New York, 2009.

Schumpeter Joseph A., The Theory of Economic Development, Transaction Publisher, London, 1982.

Schumpeter Joseph A., Capitalism, Socialism and Democracy, George Allen and Unwin, London, 1954.

Wind Joram, Mahajan Vijay, Convergence Marketing. Strategies for Reaching the Hybrid Consumer, Pearson Education, Upper Saddle River, 2002, p. 16.

Yoffie David, Competing in the Age of Digital Convergence, Harvard Business Press, Boston, 1997.

Zineldin Mosad, Co-opetition: the Organisation of the Future, Marketing Intelligence and Planning, vol. 22, n. 7, 2004.

http://dx.doi.org/10.1108/02634500410568600 